\title{
PENGARUH SAYAP TERHADAP PERKECAMBAHAN BENIH MAHONI (Swietenia macrophylla King) ASAL BKPH CIANJUR KPH CIANJUR
}

\section{Wings Cutting influenced to Mahoni ( Swietenia macrophylla King) Seeds Germination at BKPH Cianjur KPH Cianjur}

\author{
Ika Nofi Hastuti \\ Faculty of Forestry University Winaya Mukti (UNWIM) \\ E-mail :Ikanof@gmail.com
}

\begin{abstract}
To produce a good quality Mahoni (Swietenia macrophylla King) tree, besides need a good sedds, also need a good source and a good treatment too.This research is interrelated with some test treatment, to get a good seedlings from the germination treatment, with saw the genetic expression from four treatment, the germination with full seeds, seeds with $50 \%$ wings left, seeds with $25 \%$ wings left and seeds without wings.

The genetic expression from each treatment showed by plant physologize process durung the germination, by seeds germination percentage parameters, quick of seeds germination, fast of seeds growth and seeds germination values. This four parameters has been analysis with complete random model.

For quickest germination result is possessed by a seeds wihout wings, while fastest growth could be produced by a seeds with full wings.From the results of the analysis that each treatment showed a different genetic expression, seeds with $25 \%$ wings left have a high growth percentage and germination value than seeds without wings and seeds with full wings.But from all the treatment results, the best is possesessed by a seds with $25 \%$ wings left.
\end{abstract}

Keyword: Wings, Seeds, Germ Mahoni (Swietenia macrophylla King). 


\section{PENDAHULUAN}

\section{Latar Belakang}

Hutan dan Kehutanan di Indonesia memegang peranan penting dalam menunjang pembangunan nasional sebagai sumber pendapatan negara, perluasan kesempatan kerja serta sumber devisa negara dan penjaga keseimbangan lingkungan hidup.

Perum Perhutani KPH Cianjur dalam menghasilkan pendapatannya (income) sebagian besar masih menitikberatkan kepada hasil hutan berupa kayu diantaranya kayu jenis Mahoni. Mahoni merupakan salah satu jenis tanaman yang mempunyai daya tarik tersendiri salah satu kelebihannya adalah pertumbuhannya cepat dan kegunaan kayu sangat beragam.

Pemanfaatan jenis tanaman Mahoni ini digunakan untuk berbagai keperluan diantaranya kayunya cocok untuk perabot rumah tangga serta perabot ukiran. Mahoni mempunyai prospek yang sangat baik untuk dikembangkan karena memiliki kualitas kayu yang baik cukup keras, awet dan motif serta warna yang menarik. Kayu ini selain tanaman produksi bernilai ekonomis tinggi juga dapat digunakan sebagai pohon peneduh jalan karena berumur tahunan tidak mudah terkena hama penyakit, tidak mudah tumbang dengan struktur kayu yang kuat, tumbuh lurus keatas dengan tajuk tinggi diatas batas ketinggian kendaraan, pohon Mahoni ini bisa mengurangi polusi udara sekitar $47 \%$ - 69\% sehingga disebut sebagai pohon pelindung sekaligus filter udara dan daerah tangkapan air.

Untuk keberhasilan tanaman Mahoni ini maka dibutuhkan benih/bibit yang berkualitas serta teknis pemulian tanaman yang baik juga. Maka diperlukan uji kecambah dengan beberapa perlakuan diantaranya uji kecambah dengan sayap utuh, uji kecambah dengan sayap $50 \%$, uji kecambah dengan sayap $25 \%$, uji kecambah dengan biji telanjang. Diduga bahwa setiap perlakuan mempunyai karakteristik yang berbeda dalam beradaptasi dengan kondisi lingkungan, sehingga dalam upaya tindakan pemuliaan perlu uji kecambah untuk mendapatkan informasi perlakuan mana yang lebih baik pada perkecambahan Mahoni.

Dengan adanya hasil pengujian ini, diharapkan membantu penyediaan bibit Mahoni berkualitas baik dan dapat mendukung kegiatan penanaman dengan mempertimbangkan penerapan ilmu pemuliaan.

\section{Tujuan Penelitian}

Tujuan dari penelitian ini untuk mengamati ekspresi genetik perkecambahan dengan beberapa perlakuan sehingga memperlihatkan perbedaan perlakuan mana yang lebih baik.

\section{Manfaat Penelitian}

Dengan adanya penelitian ini diharapkan dapat memberikan informasi penting mengenai pengaruh sayap biji Mahoni terhadap pertumbuhan kecambah. 
Strategi pemuliaan selanjutnya dapat dilakukan berdasarkan informasi yang dieksplorasi melalui penelitian ini. Dengan harapan apa yang menjadi tujuan pengembangan Mahoni dapat tercapai.

\section{Perumusan Masalah}

Tindakan Deforestasi guna merehabilitasi dan peningkatan produktifitas lahan. Hal ini sangat penting khususnya untuk kemajuan sektor kehutanan dan ini akan tercapai apabila bibit berkualitas baik secara genetik. Bibit berkualitas baik diperoleh dari sumber benih yang teruji melalui ekspresi genetik pada awal pertumbuhan, tahap semai dan tahap pertumbuhan tanaman dilapangan. Untuk mengetahui ekspresi genetik pada awal pertumbuhan, maka dilakukan penelitian perkecambahan seperti yang tertuang pada penelitian ini.

Mahoni merupakan tanaman yang memiliki prospek pasar yang cukup menguntungkan diluar maupun di dalam negeri maka Perum Perhutani perlu melakukan upaya untuk meningkatkan poduksi dan kualitas kayu Mahoni.

\section{Hipotesa Penelitian}

Adapun hipotesis yang akan diuji dalam penelitian ini adalah bahwa beberapa perlakuan terhadap penaburan biji Mahoni mempunyai karakteristik perkecambahan dan pertumbuhan awal yang berbeda-beda. Hipotesis yang diuji adalah tidak ada pengaruh sayap yang berbeda terhadap pertumbuhan perkecambahan dan ada pengaruh sayap terhadap perkecambahan

\section{Batasan Penelitian}

Benih Mahoni yang diuji daya kecambahnya dan digunakan untuk penelitian adalah benih diambil dari hutan produksi BKPH Cianjur KPH Cianjur.

\section{METODA PENELITIAN}

\section{Waktu dan Tempat Penelitian}

Penelitian perkecamabahan benih Mahoni (Swietenia macrophylla) Asal BKPH Cianjur KPH Cianjur dilaksanakan pada bulan Oktober 2016.

\section{Alat dan Bahan}

Alat - alat yang dipergunakan dalam penelitian adalah :

1. Bak untuk penaburan benih

2. Ember

3. Hand spayer

4. Termo meter

5. Higro meter 
6. Alat tulis

Bahan - bahan yang dipergunakan dalam penelitian

1. Media Semai Pasir sungai dan tanah dengan komposisi 1:1 yang sudah disterilsasi.

2. Benih Mahoni

\section{Prosedur Penelitian}

Untuk penelitian perkecambahan benih Mahoni (Swietenia macrophylla) dilakukan melalui tahapan-tahapan sebagai berikut :

1. Persiapan benih Mahoni (Swietenia macrophylla)

Benih yang digunakan dalam penelitian ini diperoleh dari pengunduhan secara langsung dari hutan produksi BKPH Cianjur. Perlakuan pendahuluan terhadap benih yaitu benih dengan sayap utuh, benih dengan sayap $50 \%$, benih dengan sayap $25 \%$ dan benih biji telanjang masing-masing 100 dengan 3 kali ulangan total benih 1200 benih. Direndam air dingin selama 24 jam.

2. Persiapan Media Perkecambahan

a. Pengayakan pasir

b. Sterilisasi pasir kali dengan cara dikukus selama 4 jam.

c. Sterilisasi tanah (Top Soil) dengan cara dikukus selama 4 jam

d. Selanjutnya dimasukan ke dalam bak tabur sebanyak 12 bak tabur

3. Penaburan benih Mahoni (Swietenia macrophylla)

Penanaman benih Mahoni pada media tabur

4. Pemeliharaan media tabur/media tanam

Pemeliharaan berupa penyiraman yang dilakukan setiap satu hari sekali dengan volume yang sama agar pertumbuhan normal selanjutnya dilakukan penyiangan disekitar kecambah.

\section{Parameter Yang Diamati}

Parameter yang diamati dalam penelitian perkecambahan benih Mahoni (Swietenia macrophylla) ini meliputi :

1. Persentase perkecambahan benih

2. Laju Perkecambahan

3. Kecepatan tumbuh benih

4. Nilai Perkecambahan Benih (Germination Value)

\section{Rancangan Percobaan}

Rancangan percobaan yang digunakan dalam penelitian ini adalah Rancangan Acak lengkap sederhana, dalam faktorial 1 x 4 . Setiap kombinasi perlakuan diulang tiga kali dan masing-masing ulangan terdiri dari 100 sebagai satuan amatan, sehingga keseluruhan yang diamati berjumlah 1.200 benih Mahoni. 
Empat perlakuan Mahoni (Swietenia macrophylla) yang akan diuji, setiap perlakuan mendapat 3 ulangan, masing-masing terdiri dari 100 butir benih Mahoni (Swietenia macrophylla).

\begin{tabular}{|c|c|c|}
\hline IA1 & A1 & A1 \\
\hline \multicolumn{2}{|c|}{} & A2 \\
\hline A2 & A2 \\
\hline A3 & A3 & \\
\hline \multicolumn{2}{|c|}{} \\
\hline A4 & A4 & \\
\hline & & \\
\hline
\end{tabular}

Gambar 1. Desain Percobaan Penelitian

Keterangan:

A1 : Biji dengan sayap utuh

A2 : Biji dengan sayap 50\%

A3 : Biji dengan sayap 25\%

A4 : Biji dengan tanpa sayap

\section{Analisis Data}

Data hasil pengamatan dihitung dan dianalisis menggunakan SPSS 15.0 dan uji lanjut menggunakan uji Duncan untuk mengetahui pengaruh sayap terhadap perkecambahan. 


\section{HASIL DAN PEMBAHASAN}

\section{Persentase Perkecambahan Benih (Germination Percentage)}

Persentase perkecambahan benih menujukan jumlah kecambah yang dihasilkan oleh benih pada kondisi lingkungan tertentu. Rata-rata persentase kecambah benih dari 4 perlakuan berkisar $85 \%$ sampai 91,3\%. Rata-rata persentase kecambah yang tertinggi ditunjukan oleh biji Mahoni sayap 25\% dengan nilai ratarata $91,3 \%$. Urutan selanjutnya adalah sayap 50\% dengan nilai rata-rata $89 \%$, tanpa sayap dengan nilai $85,6 \%$, Sedangkan rata-rata terendah terdapat pada benih dengan perlakuan sayap utuh yaitu 85 Persen berkecambah masing-masing perlakuan disajikan pada Tabel 1 .

Tabel 1. Data Persentase Perkecambahan Benih Mahoni (Swietenia macrophylla)

\begin{tabular}{lrrrrr}
\hline Kombinasi & \multicolumn{3}{c}{ Ulangan } & Jumlah & Rata-Rata \\
\cline { 2 - 4 } Perlakuan & I & \multicolumn{1}{c}{ II } & \multicolumn{1}{c}{ III } & & \\
\hline A1 & 90 & 96 & 69 & 255 & 85,00 \\
A2 & 75 & 98 & 94 & 267 & 89,00 \\
A3 & 88 & 90 & 96 & 274 & 91,33 \\
A4 & 91 & 81 & 85 & 257 & 85,67 \\
\hline Total & $\mathbf{3 4 4}$ & $\mathbf{3 6 5}$ & $\mathbf{3 4 4}$ & $\mathbf{1 0 5 3}$ & \\
\hline
\end{tabular}

Untuk melihat nilai signifikansi dari rata-rata persentase kecambah, maka dilakukan analisis keragaman perlakuan yang hasilnya disajikan dalam Tabel 2 berikut ini.

Tabel 2. Hasil Analisis Sidik Ragam Daya Kecambah Benih Mahoni (Swietenia macrophylla)

\begin{tabular}{llllll}
\hline $\begin{array}{c}\text { Sumber } \\
\text { Keragaman }\end{array}$ & $\begin{array}{c}\text { Derajat } \\
\text { bebas }\end{array}$ & $\begin{array}{c}\text { Jml } \\
\text { Kuadrat }\end{array}$ & $\begin{array}{c}\text { Jumlah } \\
\text { kuadrat } \\
\text { tgh }\end{array}$ & $\begin{array}{c}\text { F } \\
\text { Hitung }\end{array}$ & F Tabel \\
\hline Perlakuan & 3 & 78,91 & 75,91 & 0,63 & 0,848 \\
Ulangan & 2 & 73,5 & 36,75 & & \\
Galat & 6 & 715,84 & 119,30 & & \\
Total & 11 & 868,25 & & & \\
& & & & &
\end{tabular}

Berdasarkan tabel 2 diatas menunjukan bahwa perlakuan memberikan pengaruh yang tidak beda nyata terhadap daya kecambah benih Mahoni (Swietenia macrophylla).

Menurut Daniel et al (1992), faktor-faktor yang mempengaruhi perkecambahan adalah genetika biji, air, oksigen, karbondioksida dan suhu. Pada 
penelitian ini dilaksanakan pada tempat yang sama sehingga faktor luar tidak berpengaruh terhadap perbedaan perkecambahan oleh karena itu diduga perbedaan daya kecambah selain genetik benih juga karena kualitas benih dapat dilihat dari ukuran benih yang maksimum. Diduga bahwa faktor yang menyebabkan terjadinya perbedaan daya kecambah pada penelitian ini adalah karena adanya ekspresi genetik yang berbeda pada setiap perlakuan benih. Selanjutnya untuk melihat perbedaan persentase kecambah antar perlakuan dibandingkan nilai rata-rata persentase perkecambahan disajikan pada grafik 1 dan dilakuan Uji wilayah berganda Duncan yang hasilnya disajikan pada tabel 3.

Tabel 3. Hasil Uji Wilayah Berganda Duncan Terhadap Persentase Kecambah Benih Mahoni (Switenia macrophylla)

\begin{tabular}{ccc}
\hline Kombinasi Perlakuan & Rata-Rata & Kode \\
\hline A1 & 85 & $\mathrm{a}$ \\
A2 & 89 & $\mathrm{~b}$ \\
A3 & 91,3 & $\mathrm{~b}$ \\
A4 & 85,6 & $\mathrm{a}$ \\
\hline
\end{tabular}

Keterangan : huruf yang sama berarti tidak berbeda keterangan

Pada tabel 3 dan grafik pada gambar 2, memperlihatkan persentase perkecambahan yang bervariasi perlakuan A3 sayap 25\% menghasilkan persentase kecambah tertinggi yaitu 91,3 \% perlakuan sayap utuh dan tanpa sayap menghasilkan persentase kecambah tidak berbeda nyata namun berbeda dengan perlakuan sayap $25 \%$ dan perlakuan sayap $50 \%$.

\section{Laju Perkecambahan Benih (Germination Rate)}

Laju perkecambahan benih dapat diukur dengan menghitung jumlah hari yang diperlukan untuk munculnya radikula. Laju perkecambahan yang cepat dan pertumbuhan kecambah yang cepat mencerminkan kekuatan tumbuh suatu tanaman.

Setiap benih dengan perlakuan benih yang berbeda mempunyai laju perkecambahan yang berbeda-beda, hal ini dapat dilihat berdasarkan hasil penelitian. Dimana laju perkecambahan benih Mahoni( Swietenia mahagoni) dalam penelitian ini antara 21,52 hari sampai 25,41 hari laju perkecambahan tertinggi terdapat pada perlakuan tanpa sayap (biji telanjang ) dengan rata-rata hari adalah 21,82 hari,sayap 50\% dengan rata-rata hari 24,94 hari kemudian benih dengan sayap utuh dengan rata-rata hari 25,04 hari. Sedangkan laju berkecambah terendah terdapat pada benih dengan sayap $25 \%$ rata-rata hari adalah 25,32 hari. Laju Perkecambahan masing-masing perlakuan disajikan pada Tabel 4. 
Tabel 4. Data Laju Perkecambahan Benih Mahagoni Swietenia.

\begin{tabular}{llrrrr}
\hline Kombinasi & \multicolumn{3}{c}{ Ulangan } & \multirow{2}{*}{ Jumlah } & \multirow{2}{*}{ Rataan } \\
\cline { 2 - 4 } Perlakuan & I & II & III & & \\
\hline A1 & 24,91 & 25,17 & 25,03 & 75,11 & 25,04 \\
A2 & 25,29 & 24,49 & 25,03 & 74,81 & 24,94 \\
A3 & 25,41 & 25,62 & 24,94 & 75,97 & 25,32 \\
A4 & 21,52 & 21,88 & 22,05 & 65,45 & 21,82 \\
\hline Total & $\mathbf{9 7 , 1 3}$ & $\mathbf{9 7 , 1 6}$ & $\mathbf{9 7 , 0 5}$ & $\mathbf{2 9 1 , 3 4}$ & \\
\hline
\end{tabular}

Hasil analisis data mengenai laju perkecambahan disajikan dalam tabel berikut ini.

Tabel 5. Hasil Analisis Sidik Ragam Laju Perkecambahan

\begin{tabular}{lrrrrr}
\hline $\begin{array}{c}\text { Sumber } \\
\text { Keragaman }\end{array}$ & $\begin{array}{c}\text { Derajat } \\
\text { Bebas }\end{array}$ & $\begin{array}{c}\text { Jumlah } \\
\text { Kuadrat }\end{array}$ & $\begin{array}{c}\text { Jumlah } \\
\text { Kuadrat } \\
\text { Tengah }\end{array}$ & F Hitung & F Tabel \\
\hline Perlakuan & 3 & 24,48 & 8,16 & 64,7619 & 4,757 \\
Ulangan & 2 & 0,002 & 0,001 & & \\
Galat & 6 & 0,758 & 0,126 & & \\
\hline Total & 11 & 25,24 & & & \\
\hline
\end{tabular}

Berdasarkan tabel diatas menunjukan bahwa sayap pada biji Mahoni memberikan pengaruh yang tidak beda nyata terhadap laju perkecambahan benih Mahoni. Berdasarkan tabel diatas menunjukan bahwa minimal terdapat satu perlakuan, yang mempunyai perbedaan kemampuan dalam laju perkecambahan, sehingga perlu dilakukan uji lanjut. Uji lanjut yang digunakan adalah uji lanjut Duncan yang hasilnya disajikan dalam tabel 6 berikut ini.

Tabel 6. Hasil Uji Lanjut Laju Perkecambahan

\begin{tabular}{lllc}
\hline \multicolumn{1}{c}{ Perlakuan Benih } & & N & \multicolumn{2}{c}{ Sub bagian untuk alpa $=\mathbf{0 . 0 5}$} \\
& & \multicolumn{1}{c}{} \\
\hline A1 & 3 & & 25.0367 \\
A2 & 3 & & 24.9367 \\
A3 & 3 & & 25.3233 \\
A4 & 3 & 21.8167 & \\
Sig. & 3 & 1.000 & 178 \\
\hline
\end{tabular}

Tabel 6 menunjukan bahwa perkecambahan biji telanjang berbeda nyata, dengan biji sayap utuh, biji dengan pemotongan sayap 50\%, biji dengan pemotongan sayap $75 \%$ artinya perlakuan mempunyai respon yang berbeda terhadap laju perkecambahan dari 4 perlakuan, yaitu biji tanpa sayap ( biji 
telanjang). Laju perkecambahan adalah kemampuan benih untuk tumbuh dengan cepat dan kuat.Menurut Mas'ud Poerwidodo (1992), keberhasilan pertumbuhan tanaman dikendalikan oleh genetika biji, keadaan iklim,keadaan fisik tanah, penanaman dan hara tanaman. Pada penelitian ini, keadaan iklim, keadaan fisik tanah, penanaman dan hara tanaman tidak berpengaruh terhadap perbedaan laju perkecambahan karena penelitian ini dilakukan pada kondisi dan tempat sama. Sehingga dapat diduga bahwa adanya perbedaan laju perkecambahan dipengaruhi oleh genetika biji. Urutan laju perkecambahan yang baik terdapat pada perlakuan perkecambahan dengan biji tanpa sayap, biji dengan pemotongan sayap 50\%, biji dengan pemotongan sayap $75 \%$ dan biji dengan sayap utuh.

\section{Kecepatan Tumbuh Benih (Rata-rata Harian)}

Kecepatan tumbuh digunakan untuk menaksir jumlah benih yang berkecambah pada waktu yang ditentukan. Rata-rata kecepatan berkecambah berkisar antara 86,33\% /hari (sayap utuh), $86 \%$./ hari (Biji Telanjang), 81\%/ hari (Biji dengan Pemotongan Sayap 50\%). Rata-rata kecepatan berkecambah tertinggi ditunjukan oleh perlakuan kecambah dengan sayap utuh dengan rata-rata nilai 86,33 $\% /$ hari.

Perlakuan perkecamabahan dengan sayap utuh, biji telanjang, biji dengan pemotongan sayap $75 \%$ dan biji dengna pemotongan sayap 50\% memiliki rata-rata hari berkecambah adalah 86,33\% / hari, 86\% / hari, 81\%/ hari Dan 79\% / hari. Sedangkan rata-rata kecepatan berkecambah terendah terdapat pada perlakuan perkecambahan Biji dengan pemotongan sayap 50\% yaitu 79\% / hari. Hasil analisis data untuk parameter kecepatan tumbuh masing-masing perlakuan sebagaimana tabel 7 berikut ini.

\section{Tabel 7. Hasil Analisis Sidik Ragam Kecepatan Tumbuh Benih Mahoni} (Swietenia macrophylla)

\begin{tabular}{lrrrr}
\hline $\begin{array}{c}\text { Sumber } \\
\text { Keragaman }\end{array}$ & $\begin{array}{c}\text { Derajat } \\
\text { Bebas }\end{array}$ & $\begin{array}{c}\text { Jumlah } \\
\text { Kuadrat }\end{array}$ & $\begin{array}{c}\text { Jumlah } \\
\text { Kuadrat } \\
\text { Tengah }\end{array}$ & Sig. \\
\hline Perlakuan & 3 & 56.917 & 18.972 & 0,903 \\
Galat & 8 & 819.333 & 102.417 & \\
\hline Total & 11 & 876.250 & & \\
\hline
\end{tabular}

Tabel di atas, menunjukan bahwa nilai signifikan sebesar 0,903 artinya perlakuan memberikan pengaruh yang nyata terhadap kecepatan perkecambahan benih Switenia macrophylla. Dengan demikian minimal terdapat satu perlakuan perkecambahan, yang mempunyai perbedaan kemampuan dalam kecepatan berkecambah. Untuk itu dilakukan pengujian lanjut. Hasil uji lanjut yang digunakan disajikan dalam tabel berikut ini. 
Tabel 8. Hasil Uji Lanjut Kecepatan Tumbuh Benih Swietenia macrophylla

\begin{tabular}{lll}
\hline \multirow{2}{*}{ Perlakuan } & \multirow{2}{*}{$\mathbf{N}$} & \multicolumn{1}{c}{$\mathbf{~}$ Sub Bagian Untuk Alpa $=\mathbf{0 . 0 5}$} \\
\cline { 3 - 3 } & & \multicolumn{1}{c}{$\mathbf{2}$} \\
\hline A1 & 3 & 86.3333 \\
A2 & 3 & 85.6667 \\
A3 & 3 & 81.0000 \\
A4 & 3 & 86.0000 \\
Sig. & & 559 \\
\hline
\end{tabular}

Tabel diatas menunjukan bahwa perlakuan dengan sayap utuh, mempunyai respon yang berbeda terhadap kecepatan tumbuh kecambah dari keempat perlakuatersebut, yaitu biji dengan sayap utuh.

Perkecambahan perlakuan dengan sayap utuh memiliki karakteristik kecepatan perkecambahan lebih baik dibandingkan dengan perlakuan biji dengan pemotongan sayap $75 \%$.

\section{Nilai Perkecambahan Benih Mahoni (Swietenia macrophylla)}

Nilai perkecambahan benih diperoleh dari perkalian antara energi puncak dengan rata-rata perkecambahan harian. Nilai perkecambahan benih setiap perlakuan dalam penelitian ini berbeda-beda, dimana setiap benih mempunyai kemampuan tumbuh yang berbeda juga. Dimana rata-rata nilai perkecambahan berkisar antara 24,89 (\%/hari), 24,82 (5/hari), 23,31 (\%/hari) dan 23,01 (\%/hari). Rata-rata nilai perkecambahan yang tertinggi terdapat pada perlakuan biji dengan pemotongan sayap $75 \%$,dengan rata-rata hari adalah 24,89.(\%/hari). Selanjutnya adalah 24,82 (\%/hari), 23,31 (\%/hari) dan 23,04 (5/hari), dengan nilai perkecambahan terendah terdapat pada perlakuan biji telanjang, yaitu sebesar 23,04 (\%/hari). Hasil analisis data yang untuk parameter nilai perkecambahan disajikan pada tabel berikut ini :

Tabel 9. Hasil Analisis Sidik Ragam Nilai Perkecambahan

\begin{tabular}{lllll}
\hline $\begin{array}{c}\text { Sumber } \\
\text { Keragaman }\end{array}$ & $\begin{array}{c}\text { Derajat } \\
\text { Bebas }\end{array}$ & $\begin{array}{c}\text { Jumlah } \\
\text { Kuadrat }\end{array}$ & $\begin{array}{c}\text { Jumlah } \\
\text { Kuadrat } \\
\text { Tengah }\end{array}$ & Sig. \\
\hline Perlakuan & 3 & 8.554 & 2.851 & 0.373 \\
Galat & 8 & 19.154 & 2.394 & \\
\hline Total & 11 & 27.707 & & \\
\hline
\end{tabular}

Tabel 9 diatas, menunjukkan bahwa nilai signifikansinya adalah 0,373 artinya perlakuan biji dengan pemotongan syap $75 \%$ memberikan pengaruh yang nyata terhadap perkecambahan benih Sweitenia macrophylla. dengan demikian minimal terdapat perlakuan yang mempunyai kemampuan berbeda dalam nilai perkecambahan. Oleh karena itu dilakukan pengujian lanjut uji lanjut yang 
digunakan adalah uji lanjut Duncan yang hasilnya disajikan dalam tabel 10 berikut ini.

Tabel 10. Hasil uji Lanjut Nilai Perkecambahan

\begin{tabular}{llll}
\hline \multirow{2}{*}{ Perlakuan } & \multirow{2}{*}{$\mathbf{N}$} & \multicolumn{2}{c}{ Sub Bagian untuk alpa $=\mathbf{0 , 0 5}$} \\
\cline { 3 - 4 } & & $\mathbf{1}$ & $\mathbf{2}$ \\
\hline A1 & 3 & 23.3133 & \\
A2 & 3 & 24.8167 & \\
A3 & 3 & 24.8900 & \\
A4 & 3 & 23.0400 \\
\hline
\end{tabular}

Setelah dilakukan pengujian lanjut, dapat diketahui bahwa perlakuan perkecambahan biji dengan pemotongan sayap $75 \%$ berbeda nyata dengan perlakuan biji sayap utuh, dimana yang memberikan respon yang paling tinggi terhadap perkecambahan adalah perlakuan biji dengan pemotongansayap $75 \%$. Sebaliknya yang memberikan respon yang terendah terhadap perkecambahan adalah perlakuan biji telanjang.

\section{KESIMPULAN DAN SARAN}

\section{Kesimpulan}

Kesimpulan yang bisa diambil dari penelitian ini adalah :

1. Nilai rata-rata daya kecambah tertinggi diperoleh dari perlakuan dengan pemotongan sayap $75 \%$ yaitu91,33\% dan yang paling rendah diperoleh pada perlakuan dengan sayap utuh yaitu $85 \%$.

2. Nilai rata-rata laju perkecambahan tertinggi terdapat pada perlakuan biji tanpa sayap yaitu 21,52 hari dan yang paling rendah terdapat pada perlakuan biji dengan pemotongan sayap yaitu 25,32hari.

3. Nilai rata-rata kecepatan tumbuh tertinggi terdapat pada perlakuan biji dengan sayap utuh yaitu $86,33 \%$ / hari dan yang paling rendah adalah perlakuan biji dengan pemotongan sayap 50\% yaitu $79 \%$ / hari.

4. Rata-rata nilai perkecambahan tertinggi terdapat pada perlakuan biji dengan pemotongan sayap $75 \%$ yaitu 24,89 (\%/hari) dan yang paling rendah adalah perlakuan tanpa sayap /biji telanjang yaitu 23,04 (\%/hari).

5. Dalam aspek perkecambahan diperoleh informasi bahwa perlakuan biji dengan pemotongan sayap $75 \%$ merupakan yang terbaik daya kecambah dan nilai perkecambahannya.

6. Dari hasil perkecambahan terdapat variasi genetik yang berbeda dari masing-masing perlakuan. 


\section{Saran}

Berdasarkan penelitian ini terdapat beberapa saran yang dapat disampaikan:

1. Perlu dilakukan penelitian lanjutan mengenai ekspresi genetik masingmasing perlakuan pada tarap semai dilapangan.

2. Perlakuan biji dengan pemotongan $75 \%$ bisa direkomendasikan sebagai sumber benih untuk pemuliaan pohon selanjutnya.

3. Upaya-upaya untuk meningkatkan perkecambahan adalah memperhatikan faktor-faktor yang mempengaruhi perkecambahan seperti faktor di dalam benih (kemasakan benih, ukuran benih,pematahan dormansi) maupun faktor di luar benih (air yang cukup, temperatur, oksigen, cahaya dan media).

\section{DAFTAR PUSTAKA}

Daniel, T.W, J. A. Helms, F.S.Baker .1992 Prinsip-prinsip Silvikultur. Yogyakarta : Gadjah Mada University Press.

Departemen Kehutanan.2006. Kumpulan Peraturan Perundangan Perbenihan Tanaman Hutan. Sumedang : Balai Perbenihan Tanaman Hutan Jawa dan Madura.

Harjadi M. M dan S, Setyati. 1979. Pengantar Agronomi . Jakarta : PT. Gramedia. Kuswanto, H. 1997. Analisis Benih. Yogyakarta

Mas'ud Paerwidodo, 1992. Telaah Kesuburan Tanah. Bandung : Angkasa.

Santika, S. S. 2006. Perkecambahan Benih Acacia mangium Willd. Generasi Kedua Asal KBS HPHTI PT. Musi Persada dan analisis Kelayakan Usahanya (skripsi) Jurusan Manajemen Hutan, Fakultas Kehutanan, Universitas Winaya Mukti.

Sutopo. 2002. Teknologi Benih. Jakarta : PT. Raja Grafindo Persada.

Tjitrosoepomo, G. 1985. Morfologi Tumbuhan. Yogyakarta : Gadjah Mada University Press.

Wiyono, T. 2004. Pengaruh Lama Waktu Benih Berkecambah dan Klon Jati terhadap Pertumbuhan Semai Jati (Tectona grandis) 